\title{
Need Assessment of Interactive Multimedia Based on Game in Elementary School: A Challenge into Learning in $21^{\text {st }}$ Century
}

\author{
Dwi Yuniasih SAPUTRI ${ }^{1}$, RUKAYAH ${ }^{2}$, Mintasih INDRIAYU ${ }^{3}$
}

\begin{tabular}{l} 
ARTICLE INFO \\
\hline Article History: \\
Received 06.01.2018 \\
Received in revised form \\
30.03 .2018 \\
Accepted \\
Available online 01.07.2018
\end{tabular}

\begin{abstract}
This study aimed to describe the existence of learning media and analyzed the need assessments of interac tive multimedia based on game for 5 th grade students of primary school. The method of this study was descriptive qualitative. It described the phenomena based on the situation. The method used to choose the sample was purposive sampling which chose the sample based on certain consideration. The sample of this study consisted of 147 students and 5 primary school teachers. The techniques used to collect the data were interview, questionnaire, and observation. To analyze the data, interactive analy sis was used. It consisted of: data collection, data condensation, data display, and conclusion. The result of this study showed that: (1) Primary school teacher had used learning media, such as book, picture, real object, and environment; (2) Teachers and students needed interactive multimedia based on game to support learning activity at primary school. Thus, the teachers were suggested to develop interactive multimedia based on game by involving experts to produce attractive multimedia and improve learning quality.
\end{abstract}

(C) 2018 IJERE. All rights reserved

Keywords:

\begin{abstract}
Interactive Multimedia, Game, Learning Media, Primary School.
INTRODUCTION

Learning media has important roles in learning activity because it facilitates the teachers to deliver the materials to the students in learning activities. Sanaky (2013:4) stated that learning media can enhance the effectiveness and efficiency to reach the learning goals. Asyhar (2012: 44-45) divided learning media into four. They are visual media, audio media, audio-visual media, and multimedia. Based on its classification, multimedia is one among the media which involves the students' senses the most in its application. This is because it delivers information by combining several media such as text, audio, graphic, animation, and video (Hofstetter, 2001: 16). The use of multimedia pushes students to communicate with computer interactively. It means that the user has the power to control the elements in the application of the multimedia (Sutopo, 2003: 15).
\end{abstract}

According to Darmaw an (2012: 55,56), using interactive media in learning activity can boost student's motivation because of their interests to multimedia system which provides text, picture, video, audio, and animation. This statement show s that students are attracted to learn using interactive multimedia because of its interesting display and its support to learning activity. The combination of text, picture, video, audio, and animation can be students' source of learning. Kassim, et al. (2014) has conducted research which gives the result that multimedia plays a role for students to generate flexible and original ideas. Interactive multimedia makes the learning atmosphere happier without pressure (Sanaky, 2013: 7).

Wang (2017) also conducted the similar research. The result of the study shows that the use of multimedia technology in teaching physical education can make teachers and students' activity became effective. So, it made teaching and learning activity more active and alive. Sun et al. (2014) said "using multimedia animation and games as learning media enhances the children's learning interest and efficiency". Vebrianto \& Osman (2011) had done the research about the use of multimedia. The result of the study show s that teaching and learning activity process using any kinds of constructive learning media had improved students' achievement and knowledge significantly.

Based on the reality, the use of interactive multimedia in primary school is still rare. Teachers only use traditional learning media. Besides, primary school has proper and complete learning support tools, such as books, blackboard or white board, LCD projector, and computer laboratory. Yet, the availability of the properties has not been optimized yet in teaching and learning activity. This is because most of the materials

1 dwiyuniasihsaputri@uns.ac.id, orcid.org/0000-0002-1146-5482 Universitas Sebelas Maret ${ }^{2}$ 
available on hard copy. The availability of computer laboratory can support teaching and learning activities but, the use is still for Information and Communication Technology subject and extracurricular purposes.

Primary school students are close related with cognitive, affective, and psychomotor aspect development. Santrock (2011:36) also stated that the developing of brain structure causes the capability in processing something, thinking process, making decision, and self control increase. Besides the intellectual aspect, students in primary school (7-13 years old) tend to like playing. Learning which integrates a serious game can enhance students' motivation (Erhel \& Jamet, 2013). Based on the observation result to interactive learning, it shows that interactive multimedia proposed to thematic learning is only a few which is equipped with game.

The result of the research conducted by (Babiker, 2015) showed that multimedia was effective in pedagogy so the teachers needed to develop multimedia application as learning media. Martín-Sanjosé et al. (2015) had conducted an experiment which proved statistically that the improvement of knowledge in classroom using computer games is higher than control classroom. Nusir et al. (2013) said the use of interactive multimedia in the subjects of mathematics raises the attention of learners, especially when cartoon characters are used. Navarrete (2013) has conducted research that gives results that learners have a positive chance to involve creative thinking processes in synthesizing social problem information to build their understanding through the creation of interactive and educational digital games. Based on several studies done by expert, it can be conclude that interactive multimedia has important rolein learning process. The use of interactive multimedia gives space for student to be more active in learning. Interactive multimedia w as laso affect student interest and students' achievement.

Based on the explanation above, to realize optimal learning which demands the teachers to be creative and innovative. Teachers could use the latest education tools as their innovation and to solve the problems (Iksan \& Saufian, 2017). Teacher needs interactive multimedia as a learning media. Game as one of interactive multimedia form can improve students' outcame learning. Thus, this research is conducted to analyze teachers and students' responds in the need of interactive multimedia based on game as learning media.

\section{Situation of the Problem}

There are some problems that exist in elementary school in Indonesia. First, the problem of students who still have students who have difficulty in understanding abstract-treating materials. It relates to the use of instructional media that are limited to the student's book. The material in the textbook is less interesting and overcrowded. When teachers submit less desirable material to listen to the material in the book. Students are also less responsive when called upon to answer questions.

The second problem is the question that comes from the teacher. Teachers find it difficult to deliver material due to the limited time allocation and instructional media. The newly learned material is difficult to send just by using the book media only. Teachers also experience barriers to the existing learning media in elementary schools.

Problems that is arising in terms of facilities. In primary school, there is a computer laboratory available for each student. Computer labs have good and complete conditions, but have not meant utilized for thematic learning. This can be achieved by motivational teachers to create innovative learning. Teachers occasionally use LCD projectors to display material in the form of text, images, and video. However, teachers experience obstacles because it takes a long time to prepare for the LCD projector into the classroom.

\section{Aim of the Study}

The aims of this study is to describe (1) learning media used in primary school nowadays and (2) teachers and students' needs of suitable learning media to help thematic learning in primary school, especially for $5^{\text {th }}$ grade. The finding of this study is expected to be the reference for other researcher to develop innovative interactive multimedia to be implemented in elementary school. 


\section{METHOD}

This research is a descriptive research using qualitative approach. Sukardi (2011: 157) stated that the aim of descriptive research is to give an overview fact systematically and describe the characteristics of the object of the study exactly. This research takes place in five primary schools in Surakarta, Indonesia in July to August 2017.

\section{Material}

The source of the data in this study is students and teachers, events, and documents. The technique to collect the data is through interview, questionnaire, and observation. The instruments used in this research are observation sheet, interview guide, and questionnaire. To measure the validity, source triangulation and peer investigation through discussion are used in this study.

\section{Data Analyses}

The data w as analyzed using interactive analysis as stated by Miles and Huberman (2009: 14), they are: (1) data collection, is part and parcel of data analysis activities. The data collection activity in this research is by using interview, observation and questionnaire; (2) data reduction, is the process of summarizing, selecting the essentials, focusing on the important things, removing the unnecessary. This is so that data has been shortened to provide a clearer picture, and allows researchers to collect data further; (3) data presentation, is a description of a set of arranged information that provides possible conclusions and actions. Presentation of qualitative data is presented in the form of narrative text, matrix, diagrams, tables, and graphs; (4) Conclusion, is the absolute activity of data analysis. Withdrawal of conclusions in the form of interpretation activities, namely finding the meaning of data that has been presented. Between data presentation and conclusion there is data analysis activity.

\section{FINDINGS}

Based on the interview with the students, teachers had used learning media. They are pictures, real object, and environment. Teachers had used high technology learning media, such as LCD projector, yet, they had not applied learning media which gave students a chance to use it interactively. Teachers only used one-w ay learning media that made students got bored. Students became less active because the method used was teacher centered learning.

Students got difficulties when they learn abstract materials, such as natural science and social science. It was because the media used was only picture so that the materials were difficult to be understood by students. Traditional learning media used in teaching and learning activity also made students less motivated. The students preferred to choose high technology learning media as they played their smart phone and computer. Most of students had known about interactive multimedia and view about interactive multimedia. Students needed multimedia which displayed picture, video, and animation. The display on interactive multimedia eased the students to understand the materials. Besides, if it was combined with game, the students would not feel any burden because they were learning while playing. Students liked challenging games such as adventure and action. Besides, they also liked games which challenged them to solve a problem.

Five primary school teachers were interviewed to know the learning media used and their needs related to interactive multimedia based on game. Teachers usually used learning media such as book, picture, real object, and environment. Sometimes, LCD projector w as used to display picture and video.

There had not been a media facilitated various students' style of learning which made students more active and independent in classroom teaching and learning activity. The use of computer laboratory was for Information and Communication Technology subject purposes only. Most of teachers had known about interactive multimedia and its preview, but most of them had not used it. Some of them used multimedia but not the interactive one, for example in DVD form. So, they need interactive multimedia based on game to facilitate students actively and independently. Besides, the use of it is related to today's student characteristics. 
Based on observation in five primary schools, the media that were teacher used in the classroom were book, picture, and real object. The students were fewer enthusiasts because it did not involve students actively. The media was not attractive too. Sometimes, some students talked to their friends, did not pay attention to their teacher's explanation, and too busy with their own world. It made students had low understanding to the related material.

In primary school, there were complete facilities of computer and LCD projector, yet the teachers had not been utilize it optimally. Computer laboratory facilities were sufficient for all students, yet it was only used for Technology and Information subject purposes only. While teachers seldom used LCD projector because it took time to prepare it. It was only used for displaying picture and video by using power point presentation.

Students' and teachers' need assessment analysis about interactive multimedia based on game was got from questionnaire. The result of the questionnaire is shown on the table 1 and 2 below.

Table 1. Students' Need Assessment Analysis about Interactive Multimedia Based on Game

\begin{tabular}{|c|c|c|c|}
\hline \multirow{2}{*}{ Aspect } & \multirow{2}{*}{ Questions } & \multicolumn{2}{|c|}{ Answer } \\
\hline & & Yes & No \\
\hline \multirow{3}{*}{$\begin{array}{l}\text { Female Students' } \\
\text { limitation and difficulties } \\
\text { on chapter } 4 \text { sub the me } 1 .\end{array}$} & $\begin{array}{l}\text { 1. Does it ease you to learn chapter } 4 \text { sub } \\
\text { theme } 1 \text { by using learning media? }\end{array}$ & $34 \%$ & $65 \%$ \\
\hline & $\begin{array}{l}\text { 2. Do you get any difficulties on learning } \\
\text { chapter } 4 \text { sub theme } 1 \text {. }\end{array}$ & $61 \%$ & $38 \%$ \\
\hline & $\begin{array}{l}\text { 3. Are you interested an active on thematic } \\
\text { learning? }\end{array}$ & $46 \%$ & $53 \%$ \\
\hline \multirow{2}{*}{$\begin{array}{l}\text { The availability of } \\
\text { facilities and supporting } \\
\text { learning media. }\end{array}$} & $\begin{array}{l}\text { 4. Does your school have computer laboratory } \\
\text { which can use by students? }\end{array}$ & $80 \%$ & $19 \%$ \\
\hline & 5. Can you operate computer? & $100 \%$ & $0 \%$ \\
\hline \multirow{5}{*}{$\begin{array}{l}\text { The needs of media } \\
\text { based on game. }\end{array}$} & 6. Do you know about interactive multime dia? & $54 \%$ & $46 \%$ \\
\hline & $\begin{array}{l}\text { 7. Have your teachers used interactive } \\
\text { multimedia on thematic learning? }\end{array}$ & $38 \%$ & $61 \%$ \\
\hline & $\begin{array}{l}\text { 8. Does your teachers made interactive } \\
\text { multimedia on thematic learning? }\end{array}$ & $19 \%$ & $81 \%$ \\
\hline & $\begin{array}{l}\text { 9. Have your teachers used interactive } \\
\text { multimedia combined with game? }\end{array}$ & $19 \%$ & $81 \%$ \\
\hline & $\begin{array}{l}\text { 10. Do you need more interactive multimedia } \\
\text { based on game to learn chapter } 4 \text { sub theme } \\
1 \text { ? }\end{array}$ & $100 \%$ & $0 \%$ \\
\hline
\end{tabular}

Table 1 shows that the process of thematic learning activity in primary school has not been optimized yet, moreover in the use of learning media. Limitations and difficulties aspect on providing the media can be found on questions number 1,2, and 3. On question number one, $34 \%$ students are helped by the learning media. Based on question number two $61 \%$ students feel difficulties to learn the material through the learning media used by the teachers. It affects to students' enthusiasm in learning activity which is proved on question number three. There are $46 \%$ students agree about it.

The aspects showing the availability and supporting tools are explained on questions number 4 and 5 . Question number for shows that $80 \%$ students agree that school has tools to support the use of interactive media. $100 \%$ students can operate computer. It is proved on the question number five.

The aspects about the need of media, especially interactive media based on games are explained on questions number $6,7,8,9$, and 10 . Question number six shows that $54 \%$ students know about interactive multimedia. Only a few teacher use interactive multimedia. It is proved on question number seven $38 \%$ agree about it. Question number eight shows that 19\% students agree that teachers had made their own interactive multimedia. Question number nine shows that 19\% students agree that teachers have used 
Saputri,D.Y., Rukay ah, \& Indriayu,M. (2018). Need assessment of interactive multimedia based on game in elementary school: a challenge into learning in 21st century. International Journal of Educational Research Review,3(3),1-8.

interactive multimedia based on games. Based on student's respond on question number ten, $100 \%$ students need interactive multimedia based on game.

Analysis of variance results of pedagogical formation certification program students' attitudes tow ards teaching profession in the sense of level of education can be seen in Table 3.

Table 2. Teachers' Need Assessment Analysis about Interactive Multimedia Based on Game

\begin{tabular}{|c|c|c|c|}
\hline \multirow{3}{*}{$\begin{array}{c}\text { Aspect } \\
\text { Students' limitation and } \\
\text { difficulties on chapter } 4 \\
\text { sub theme } 1 .\end{array}$} & \multirow{2}{*}{ Questions } & \multicolumn{2}{|c|}{ Answer } \\
\hline & & $\begin{array}{l}\text { Yes } \\
40 \%\end{array}$ & \multirow{2}{*}{$\frac{\text { No }}{60 \%}$} \\
\hline & $\begin{array}{l}\text { 1. Do you have any difficulties inusing } \\
\text { learning media? (for example the a vailability } \\
\text { of learning media) }\end{array}$ & $40 \%$ & \\
\hline & $\begin{array}{l}\text { 2. Does the a vailability of learning me dia affect } \\
\text { the students' ability to understand chapter } 4 \\
\text { sub theme } 1 \text { ? }\end{array}$ & $20 \%$ & $80 \%$ \\
\hline & $\begin{array}{l}\text { 3. Do you have any difficulties on teaching } \\
\text { chapter } 4 \text { sub theme } 1 \text { ? }\end{array}$ & $100 \%$ & $0 \%$ \\
\hline The availability of & 4. Do you have personal computer? & $100 \%$ & $0 \%$ \\
\hline $\begin{array}{l}\text { facilities and supporting } \\
\text { learning media. }\end{array}$ & $\begin{array}{l}\text { 5. If, the answer of question number } 4 \text { is yes, } \\
\text { do you use your computer to te ach chapter } 4 \\
\text { sub theme } 1 \text { ? }\end{array}$ & $60 \%$ & $40 \%$ \\
\hline \multirow{5}{*}{$\begin{array}{l}\text { The needs of media } \\
\text { based on game. }\end{array}$} & 6. Do you know interactive multimedia? & $100 \%$ & $0 \%$ \\
\hline & 7. Have you used interactive multimedia? & $40 \%$ & $60 \%$ \\
\hline & $\begin{array}{l}\text { 8. Have you made interactive multimedia by } \\
\text { yourself? }\end{array}$ & $40 \%$ & $60 \%$ \\
\hline & $\begin{array}{l}\text { 9. Have you used interactive multimedia } \\
\text { combined with game? }\end{array}$ & $20 \%$ & $80 \%$ \\
\hline & $\begin{array}{l}\text { 10. Do you need interactive multimedia based } \\
\text { on games to teach chapter } 4 \mathrm{sub} \text { theme } 1 \text { ? }\end{array}$ & $100 \%$ & $0 \%$ \\
\hline
\end{tabular}

Table number 2 shows teachers' respond through questionnaire distributed to the primary school teachers in the form of pictures. The numbers of questions on the questionnaire are 10 questions. Question number one shows that there are two teachers found difficulties in operating learning media. All teachers agree that learning media can improve students' ability. It is proved on question number two. Question number three shows that there is one teacher found difficulties to deliver the materials through learning media.

All teachers in the primary school have their own personal computer. It is shown on the question number for. But, those computers have not been optimized yet to make learning media. It is proved on question number five which shows that there are two teachers who use their personal computers to make learning media. All teachers know about interactive multimedia. It is proved on question number six. The use of interactive multimedia is still rare in primary school. It is shown on question number seven. There are only two teachers who have used interactive multimedia in teaching and learning activity.

Question number eight proved that there are only two teachers who have made interactiv e multimedia. Interactive multimedia made by the teachers has not used any learning models yet. It is proved on question number nine. There is no teacher has used interactive multimedia based game. Question number ten shows that all teachers agree if there is a development on interactive multimedia based on games.

\section{RESULT, DISCUSSION, AND SUGGESTIONS}

Based on interview, observation, and questionnaire, teachers had used learning material such as picture, real object, and environment. Teachers more often use the book as a medium of learning. It is in accordance with the opinion of Darsono, et. al. (2018) that the textbook conditions on the ground have not shown good availability yet. This can be proved by looking at the facts of documentation in the field that the 
teacher in the process of learning activities using the book package that has been published. The students are less enthusiastic, less explorative, and become lazy in fostering imaginative ideas. Mulyanto et. Al (2018) argues that students are accustomed to receiving lessons from teachers and not trying to find or form their own knowledge.

Some of primary schools in Surakarta have computer laboratory which only used for Information and Communication Technology subject purposes only. Teachers never utilized computer laboratory facilities to use interactive multimedia. Some of teachers used their personal computer to display material through LCD projector. It took time to prepare it, so the teachers seldom used it.

All this time, learning media helped students to understand the material although it was not optimal yet. As Sanjaya (2007: 172) said that learning media could increase 70\% information to be remembered compared to information got from speech method. Sanaky (2013: 6) said that learning media could help students understand the materials systematically so it made the students easier to understand the materials. Learning media which provided picture only did not help students to understand the materials.

The suitable media for students is interactive multimedia. "Multimedia learning tools could assist and help motivate students by supplementing traditional teaching modalities with learner-centered learning through application and practice" (Son \& Simonian, 2016). Interactive multimedia combined with games could help students to understand the material because it suited students' characteristics who loved playing. Adkins (2014) also said that video games could improve students' cognitive skills such as memory skill and speed of reaction. "The tool of an educational game brings the psychological need and benefits in the learning process and it has become mainstream streams for educators, governments, and parents" (Wijayanto \& Siradj, 2012).

The use of learning media which did not suit with the students made them less motivated in teaching and learning activity. Learning media such as picture and real object made students less enthusiast in teaching and learning activity. As Sanaky (2013:6) said that media makes learning activity could be varied so can improve students' motivation. So, teachers need to use various and interesting learning media such as interactive multimedia based on game. Students liked challenging games such as adventure and action. They were challenged to follow the plots and solve the problem. Besides, they also liked games which gave them challenge to solve the problem like riddles.

Nowadays, students surrounded by high technology which taught them to adapt. As Keengwe \& Georgina (2013) said that the way to teach natives about digital world was by integrating technology in teaching and learning activity as students' interest. Heafner (2004) said that, "Students enjoyed learning by using technologies because it was interesting and pleasant." One application that is by using interactive multimedia. "Utilization of multi-media will give big impact on the students' spirit of learning (Riyanto \& Gunarhadi, 2017). But, the utilization of technology like interactive multimedia was rarely used in primary school. Like Keengwe et al. (2013) said, although technology had rapid movement, but it had not been implemented in teaching and learning activity.

Teachers had their own personal computer, yet it was rarely used to improve teaching and learning activity. As the research conducted by Kurt (2013) said that teachers use technology for the purpose of administration, not for teaching. Teachers sometimes used their computer to display picture and video. Kafyulilo \& Keengwe (2013) also had conducted the research and the result was, "Few teachers used computers for teaching and learning purposes while majority of them used computers for administrative purposes". Teachers had limitation on time and ability to develop interactive multimedia. So, they had to cooperate with experts in technology to develop interactive multimedia which fitted with students' characteristics.

Teachers should be adaptive to start believing that integrating technology in the classroom is an effective way to improve the quality of education (Fauzi, et al., 2012). Keengwe \& Hussein (2014) also recommended the teachers, school administrators, and stake holders to integrate technology. The application of technology needed cooperation with other elements to conduct high quality of education so could improve students' achievements. 
Based on the research, it can be concluded that (1) teachers had used learning media such as pictures, concrete model, and things could be found around the environment during learning process; (2) teachers and students need interactive multimedia based on game because it is appropriate with students' characteristics who still like playing and give students chance to regulate themselves in learning activity to me more independent.

Based on the result of the research, there are some suggestions. The analysis shows that it is needed to develop interactive multimedia based on game to help the students and teachers understand and master the materials in learning process. Students liked challenging game which stimulated them to think harder to solve the problem such as adventure, riddle, and action. This research might be continued to the stage of implementing and developing the interactive multimedia based on game. Teacher could cooperate with experts to develop interactive multimedia so it could improve learning performance and students' achievements.

\section{REFERENCES}

Adkins, M. (2014). How video games and digital literacy impacts student attainment and development : an analysis of synergistic integration. Society for Information Technology \& Teacher Education International Conference. United States: Association for the Advancement of Computing in Education (AACE).

Asyhar, R. (2012). Kreatif mengembangkan media pembelajaran. Jakarta: Gaung Persada.

Babiker, M. E. A. (2015). For effective use of multimedia in education, teachers must develop their own educational multimedia applications. Turkish Online Journal of Educational Technology, 14(4), 62-68.

Darsono, Winarno, \& Slamet. (2018). The Need Textbook Writing of Children's Story Based on Character Education. International Journal of Educational Research Review, 3(2), 1-8.

Darmaw an, Deni. (2012). Inovasi pendidikan. Bandung: PT Remaja Rosdakarya.

Dwi Riyanto, W., \& Gunarhadi. (2017). The effectiveness of interactive multimedia in mathematic learning: utilizing power points for students with learning disability. International Journal of Pedagogy and Teacher Education (IJPTE), 1(1), 7-8.

Erhel, S., \& Jamet, E. (2013). Digital game-based learning: Impact of instructions and feedback on motivation and learning effectiveness. Computers and Education, 67, 156-167.

Fauzi, A., Damayanti, D., \& Ilahi, T. (2012). A teacher's beliefs on the integration of video technology in teaching speaking: a case study. International Journal of Pedagogy and Teacher Education (IJPTE), 11(1), $46-54$.

Heafner, T. (2004). Using technology to motivate students to learn social studies. Contemporary Issues in Technology and Teacher, 4(1), 42-53.

Hofstetter. (2001). Multimedia literacy third edition. Mc Graw-Hill International Edition: New York

Iksan, Z. H., \& Saufian, S. M. (2017). Mobile learning: Innovation in teaching and learning using telegram. International Journal of Pedagogy and Teacher Education (IJPTE), 11(1), 19-26.

Kafyulilo, A., \& Keengwe, J. (2013). Teachers' perspectives on their use of ICT in teaching and learning: A case study. Education and Information Technologies, 19(4), 913-923.

Kassim, H., Nicholas, $\mathrm{H} .$, \& Ng, W. (2014). Using a multimedia learning tool to improve creative performance. Thinking Skills and Creativity, 13,9-19.

Keengwe, J., \& Georgina, D. (2013). Supporting digital natives to learn effectively with technology tools. International Journal of Information and Communication Technology Education, 9(1), 51-59.

Keengwe, J., \& Hussein, F. (2014). Using computer-assisted instruction to enhance achievement of English language learners. Education and Information Technologies, 19(2), 295-306. 
Saputri,D.Y., Rukay ah, \& Indriay u,M. (2018). Need assessment of interactive multimedia based on game in elementary school: a

challenge into learning in 21st century. International Journal of Educational Research Review,3(3),1-8.

Keengwe, J., Onchwari, G., \& Agamba, J. (2013). Promoting effective e-learning practices through the constructivist pedagogy. Education and Information Technologies, 19(4), 887-898.

Kurt, S. (2013). Examining teachers' use of computer-based technologies: A case study. Education and Information Technologies, 18(4), 557-570.

Martín-Sanjosé, J. F., Juan, M. C., Seguí, I., \& García-García, I. (2015). The effects of computer-based games and collaboration in large groups vs. collaboration in pairs or traditional methods. Computers and Education, 87, 42-54.

Miles, M. B. \& A. Michael Huberman. (2009). Analisis data kualitatif. Jakarta: UI-Press.

Mulyanto, Heri, Gunarhadi \& Mintasih Indriayu. (2018). The effect of problem based learning model on student mathematics learning outcomes viewed from critical thinking skills. International Journal of Educational Research Review, 3(2), 37-45.

Navarrete, C. C. (2013). Creative thinking in digital game design and development: A case study. Computers and Education, 69,320-331.

Nusir, S., Alsmadi, I., Al-Kabi, M., \& Sharadgah, F. (2013). Studying the impact of using multimedia interactive programs on children's ability to learn basic math skills. E-Learning and Digital Media, 10(3), 305-319.

Sanaky, Hujair AH. (2013). Media pembelajaran interaktif-inovatif. Yogyakarta: Kaudaba Dipantara.

Sanjaya, Wina. (2007). Strategi pembelajaran berorientasi standar proses pendidikan. Jakarta: Kencana

Santrock, John W. (2011). Educational psychology. New York: McGraw Hill Companies, Inc.

Son, B., \& Simonian, M. (2016). An integrated multimedia learning model vs. the traditional face-to-face learning model: An examination of college economics classes. Journal of Educational Multimedia and Hypermedia, 25(4), 305-321.

Sukardi. (2011). Metodologi penelitian pendidikan. Jakarta: Bumi Aksara.

Sun, C.-C., Lo, Y.-H., \& Wang, G.-C. . (2014). The impact of applying interactive multimedia materials to English teaching practices on children's learning of English. In International Conference on Innovation, Communication and Engineering, ICICE 2014 (pp. 559-567).

Sutopo, Ariesto Hadi. (2003). Multimedia interaktif dengan flash. Yogyakarta: PT. Graha Ilmu.

Vebrianto, R., \& Osman, K. (2011). The effect of multiple media instruction in improving students' science process skill and achievement. Procedia - Social and Behavioral Sciences, 15, 346-350.

Wang, Z. (2017). Study on the multimedia application in college aerobics teaching: A learning interactive perspective. Revista de La Facultad de Ingenieria, 32(2), 759-767.

Wijayanto, P. W., \& Siradj, Y. (2012). The educational game "Indonesian Tribes" for the kindergarten students. International Journal of Pedagogy and Teacher Education (IJPTE), 11(4), 27-36. 